\title{
THE IDENTITY OF THREE FABRICIAN CHRYSIDID SPECIES (HYMENOPTERA)
}

\author{
By LyNn SiRi KimSEY* \\ Department of Entomology, \\ University of California, Davis 95616
}

As part of a world revision of the family Chrysididae it has been necessary to borrow or study in situ as many of the oldest types as possible because of potential confusion about their identity. The species described by Fabricius represent a particular problem. He named many of the commonest European species, as well as other less common ones. Although the majority of Fabrician type specimens are still extant, it is clear that the chrysidid types were never seen by most later workers. In several instances the Fabrician species was assumed to be one thing when in fact it belonged to an entirely different genus. One example of this was Chrysis festiva Fabricius, which has always been considered a Pentachrysis, or Chrysis with 5 apical abdominal teeth (Mocsáry 1889, Dalla Torre 1892, Bischoff 1913). However, festiva is actually a species of Parnopes, as discussed by Kimsey (1987). The three species below present similar problems.

\section{Omalus gloriosa (Fabricius), N. STATUS}

Chrysis gloriosa Fabricius 1793: 242. Holotype female; "Barbaria" (Kiel Coll., Copenhagen).

The name gloriosa has long been used for one of the most commonly collected species of Holopyga in the Palearctic Region (Dahlbom 1854, Mocsáry 1889, Dalla Torre 1892, Bischoff 1913). Holopyga amoenula Dahlbom was listed as a junior synonym of gloriosa by Bischoff (1913) and later by Bodenstein (1939), which made gloriosa the defacto type of Holopyga. However, amoenula is the designated type.

${ }^{*}$ Current address: Museum of Comparative Zoology-Entomology, Harvard University, Cambridge MA 02138.

Manuscript received by the editor April 7, 1987. 
Examination of the gloriosa type revealed that it is actually an Omalus, conspecific with Omalus auratus (Linnaeus) 1758, and therefore a junior synonym of that species.

\section{Holopyga fervida (Fabricius)}

Chrysis fervida Fabricius 1781: 457. Type ?; Italy (lost ?).

Chrysis fervida Fabricius 1787: 283. Four specimens; Spain (Kiel Coll., Copenhagen). Holopyga fervida of authors.

Kimsey (1986) designated a lectotype of this species in the Lepeletier collection in the Museum National d'Histoire Naturelle, Paris from a series of specimens labeled as Fabrician types. However, these specimens were from the Paris area. In the oldest description of this species (1781) Fabricius gives Italy as the type locality. Zimsen (1964) was unable to locate this type (or types?). As a result, it must be assumed that the original type has been lost. Fabricius later described the species from 4 specimens from Spain. Therefore the specimen from Paris labeled lectotype is actually an invalid type.

In his 1787 description of fervida Fabricius states "An distincta species?". Whether this means that these specimens represent a different species from the one he described in 1781 is unclear. However, since he did call these fervida and the original specimen(s) cannot be located, it is important to designate one of these a neotype. Designation of a neotype is necessary for 2 reasons: (1) one of these 4 specimens is a species of Hedychridium, not Holopyga, and (2) fervida is a common European species, so the name should be associated with a type specimen. Therefore, I am designating a female from the Kiel Collection, which is in reasonably good condition and is a typical fervida as described by other workers.

\section{Chrysis purpurata Fabricius}

Chrysis purpurata Fabricius 1787: 283. Lectotype male; "Halae Saxonom" (Kiel Coll., Copenhagen). New designation.

Chrysis iris Christ 1791: 405. No type data available. New synonymy.

Euchroeus purpurata of Latreille 1809: 49 (\#578).

As with gloriosa the name purpurata has been used for the commonest species of "Euchroeus" in Europe. This species was designated as the type of Euchroeus by Latreille 1809. Unfortunately, examination of the 3 syntypes of purpurata in the Kiel Collection revealed that they are typical Chrysis and not what is supposed to be 
Euchroeus. The shape and dentition of the apical rim of the abdomen, body color, punctation and facial structure indicate that purpurata is the senior synonym of Chrysis iris Christ. Because Latreille (1809) designated purpurata the type of Euchroeus, and this species is in fact a typical Chrysis Linnaeus, Euchroeus is therefore a junior synonym of Chrysis. Although some argument could be make for conserving the name Euchroeus this is a relatively rare group of species occurring in the Palearctic and Ethiopian Regions, which has never had a major revision. The next available name for this genus is Brugmoia Radoszkowski 1877 (type: Brugmoia pellucida Radoszkowski 1877).

\section{SUMMARY}

The true identity of 3 chrysidid species, Chrysis gloriosa, fervida and purpurata, described by Fabricius are determined. A lectotype is designated for purpurata. Chrysis gloriosa is a junior synonym of Omalus auratus (Linnaeus) 1758. Chrysis purpuratus is the senior synonym of iris Christ 1791; it is also the type of Euchroeus Latreille, making Euchroeus a junior synonym of Chrysis Linnaeus. The next available name for the genus previously called Euchroeus is Brugmoia Radoszkowski 1877. Chrysis fervida is actually a Holopyga, and a neotype is designated for this species.

\section{ACKNOWLEDGMENTS}

The kind assistance of Ole Lomholdt made this study possible. This research was supported by NSF Research Grant No. BSR-86-00341.

\section{Literature Cited}

Bodenstein, W. G. 1939. The genotypes of the Chrysididae. Trans. Amer. Ent. Soc. 65: 123-133.

BischOFF, H. 1913. Chrysididae. Genera Insectorum. (151): 1-85.

Christ, J. L. 1971. Naturgeschicte, classification und Nomenclatur der Insecten vom Bienen, vespen und Ameisengeschlicht. 535 pp. Hermannischen Buchhandlung, Frankfurt am Main.

Daнlвом, A. G. 1854. Hymenoptera Europea praeciue borealia etc. Vol. 2, xxiii $+411 \mathrm{pp}$. Lundbergiana, Lund.

Dalla Torre, C. G. 1892. Chrysididae. Catalogus Hymenopterorum 6: 1-118.

Fabricius, J. C. 1781. Species insectorum etc. Vol. 1., C. E. Bohni, Hamburg, pp. 454-457. 
1787. Species insectorum etc. Vol. 2, 382 pp. Proft, Hafniae. C. Richard, Brunsvigae.

1793. Entomologia systematica emendata et aucta etc. Hafniae. C. G. Proft 4(2): 184-185, 238-243.

Kimsey, L. S. 1986. Designation of chrysidid lectotypes. Pan-Pac Ent. Soc. 62: 105-110.

- 1987. Review of the subfamily Parnopinae. J. Kansas Ent. Soc. 60: 83-91.

Latreille, P. A. 1796. Precis des characteres generiques des Insectes etc. Brive et Bordeaux.

MOCSÁRY, A. 1889. Monographia chrysididarum orbis terrestris universi. Budapest, Academia Scientarum Hungarica, 643 pp.

Radoszkowsi, O. 1877. Chrysidiformis, Mutillidae a Sphecidae. In Reise in Turkestan, A. Fedtshenko, ed. Zool. Theil, vol. 2, i-ii + 27 pp.

Zimsen, E. 1964. The type material of I. C. Fabricius. Munksgaard, Copenhagen. 

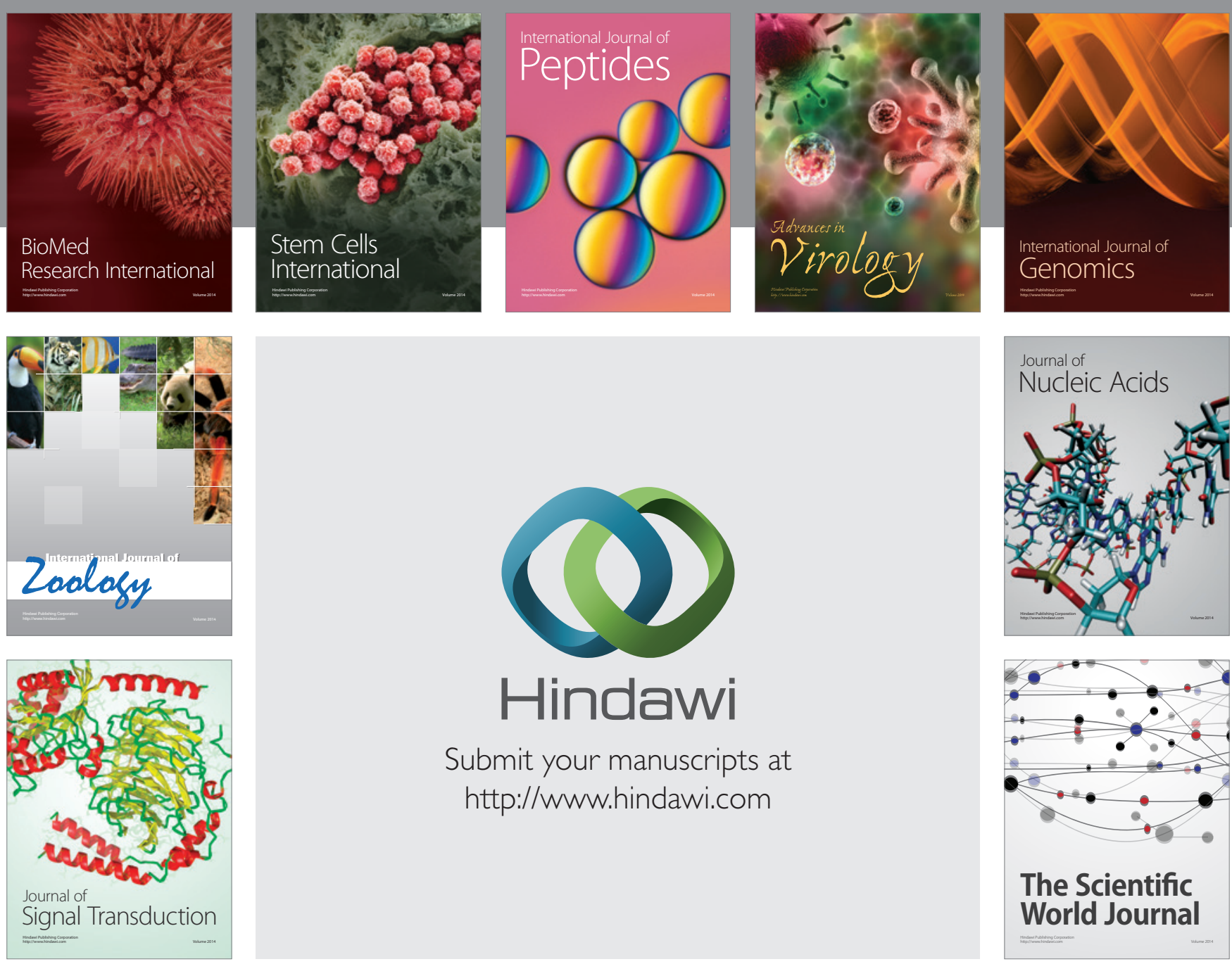

Submit your manuscripts at

http://www.hindawi.com
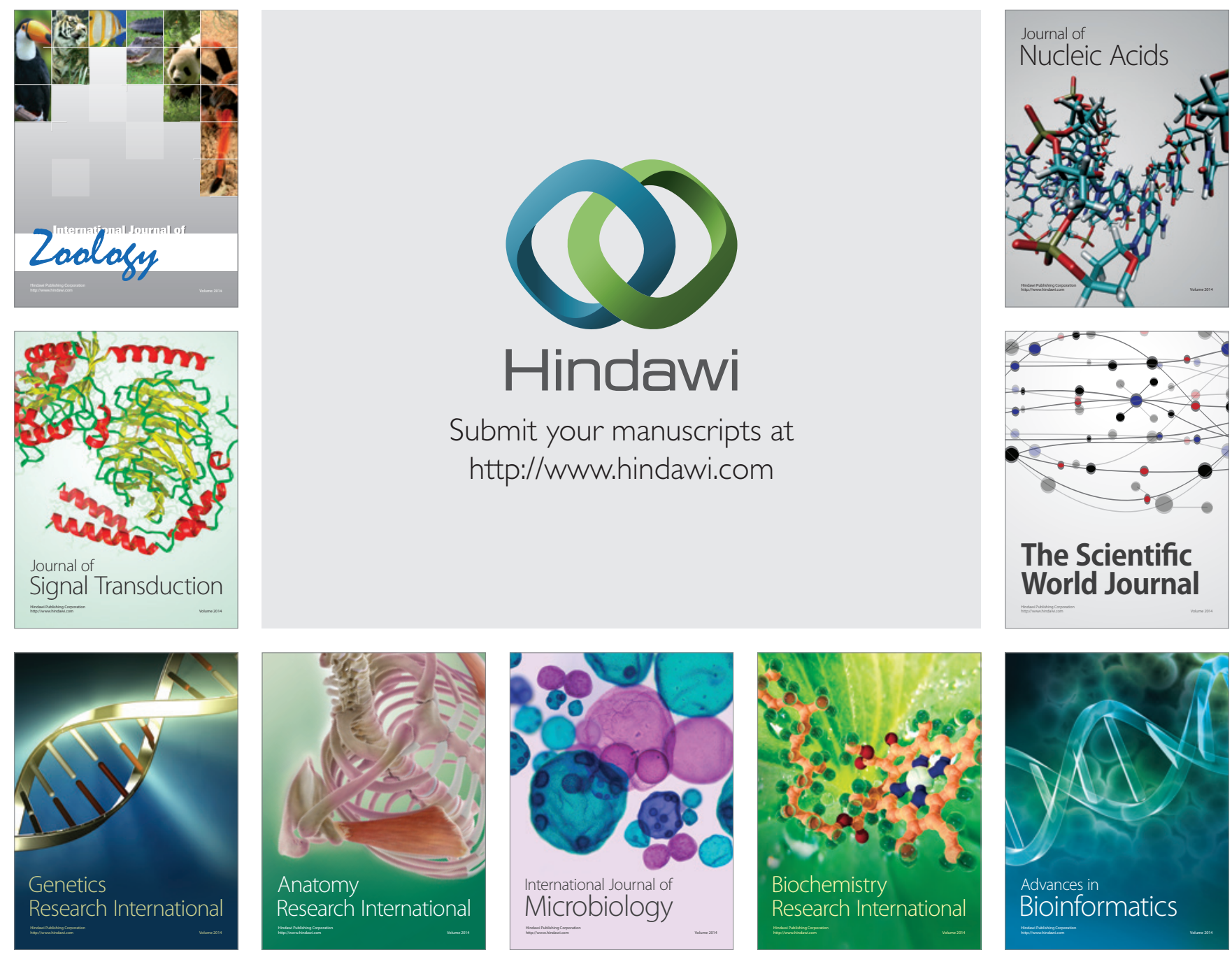

The Scientific World Journal
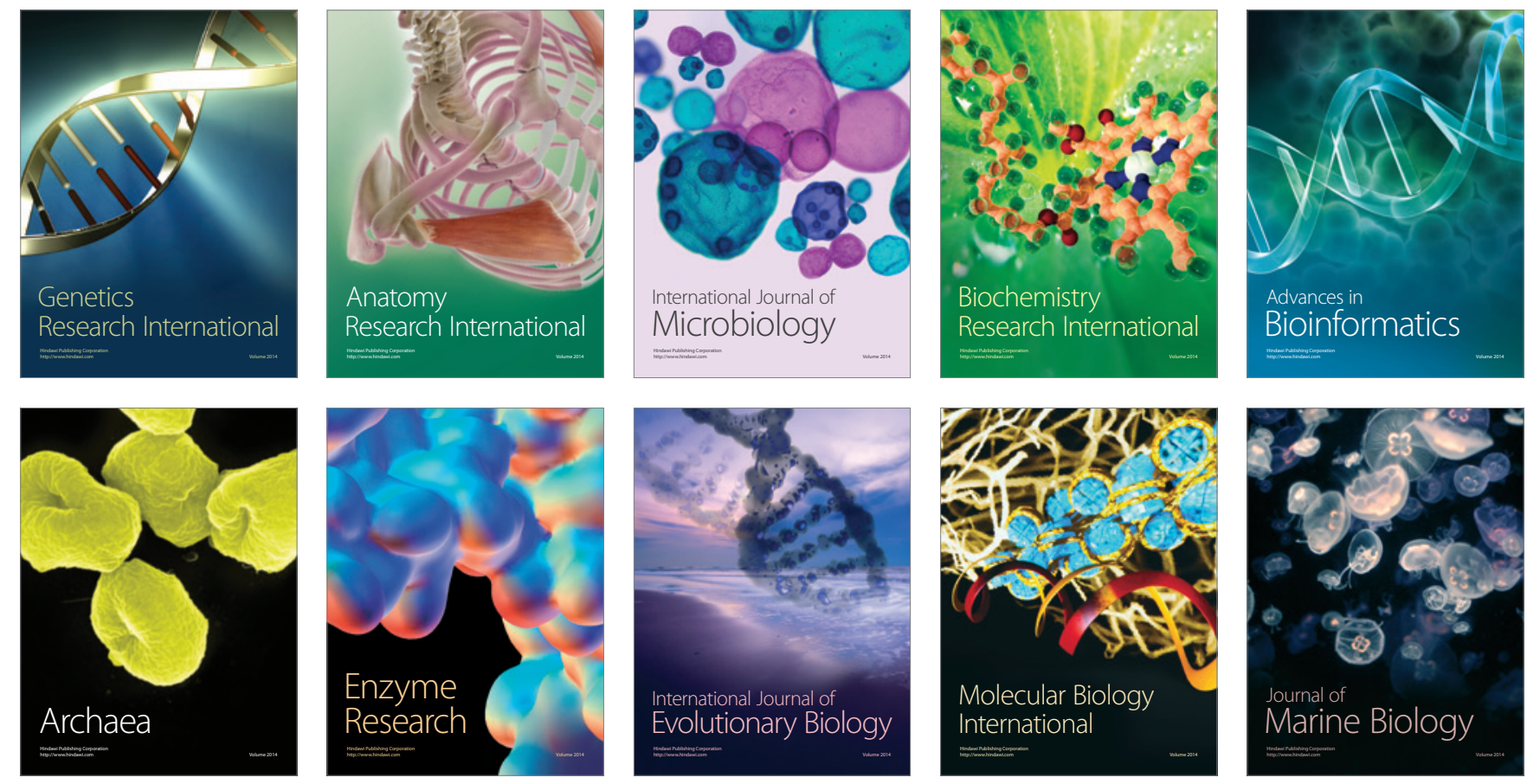